\title{
Syntheses and Refractive-Indices Properties of Novel Octa-Arms Star-Shaped Polysulfides Radiating from $p$-t-Butylcalix[8]arene Core
}

\author{
Hiroto Kudo, ${ }^{1}$ Hajime Inoue, ${ }^{1}$ Tadatomi Nishikubo, ${ }^{1, \dagger}$ and Tetsuo AnAdA ${ }^{2}$ \\ ${ }^{1}$ Department of Applied Chemistry Faculty of Engineering, Kanagawa University, \\ 3-27-1, Rokkakubashi, Kanagawa-ku, Yokohama 221-8686, Japan \\ ${ }^{2}$ Department of Electrical, Electronics and Information Engineering Faculty of Engineering, \\ Kanagawa University, 3-27-1, Rokkakubashi, Kanagawa-ku, Yokohama 221-8686, Japan
}

(Received September 5, 2005; Accepted November 5, 2005; Published March 15, 2006)

\begin{abstract}
Octa-arms star-shaped polysulfides poly $\left(\operatorname{PPS}_{(n)}-\mathrm{BCA}[8]_{\text {core }}\right)(n=5,10,15,20,30,40,50,60$, and 70) with high refractive-index were synthesized by the radiating from $p$-t-butylcalix[8]arene derivative as a core. The continuous insertion reaction of 3-phenoxypropyrenesulfide (PPS) into thioester moieties of BCA[8]-core was perfomerd in the presence of TBAC as a catalyst to afford the star-shaped polymers poly $\left(\mathrm{PPS}_{(n)}-\mathrm{BCA}[8]_{\text {core }}\right)$ quantitatively. The arm-lengths of poly $\left(\mathrm{PPS}_{(n)}-\mathrm{BCA}[8]_{\text {core }}\right)$ were controlled by the feed ratios of $[\mathrm{PPS}] /[(\mathrm{BCA}[8]-$ core $) \times 8]$. The refractive-indices values $\left(n_{\mathrm{D}} \mathrm{s}\right)$ of poly $\left(\mathrm{PPS}_{(n)}-\mathrm{BCA}[8]_{\text {core }}\right)$ increased with their sulfur contents. Furthermore, we examined the $n_{\mathrm{D}} \mathrm{S}$ of the linear polymers poly $\left(\mathrm{PPS}_{(n)}\right.$-Bphe) which skeletons are almost the same as the star-shaped polymers poly $\left(\operatorname{PPS}_{(n)}-\mathrm{BCA}[8]_{\text {core }}\right)$. It was found that $n_{\mathrm{D}} \mathrm{S}$ of star-shaped polymer were higher than those of linear ones due to their compact structures and high segment densities. [DOI 10.1295/polymj.38.289]

KEY WORDS Refractive-Index / Star-Shaped Polymer / Polysulfide / Insertion Reaction / Thiirane / Thioester /
\end{abstract}

The synthesis and properties of the polymers containing aromatic rings, heavy metals, halogens, and sulfur atoms have been of great interest for the development of high-refractive-indices materials. ${ }^{1}$ It is well known that the Abbe numbers of the polymers tended to decrease with increase of their refractive-indices values. Among them, the sulfur-containing polymers show high values of refractive-indices and relatively high Abbe numbers; that is, the wide spread of values of refractive-indices at the certain wavelengths can be depressed..$^{2,3}$ Furthermore, the synthesis of sulfur-containing polymers such as polysulfides, polysulfoxides, polysulfones, polydisulfides, and polythioesters have been reported by the various polymerizations, such as ring-opening polymerization, ${ }^{4}$ polycondensation, ${ }^{5}$ and polyaddition, ${ }^{6}$ which are almost produces as linear-chain polymers.

Meanwhile, star-shaped polymers are one of the nonlinear polymers and have much attractive attention due to their compact structures and high segment densities. $^{7}$ The various star-shaped polymers of well defined architectures have been reported by many efficient synthetic methods, such as living anionic polymerization, ${ }^{8-10}$ living cationic polymerization, ${ }^{11-15}$ and living radical polymerization. ${ }^{16-22}$ Generally, star-shaped polymers can be prepared by the two methods; that is "arm-first" and "core-first" methods. Kennedy ${ }^{23-26}$ et al. reported the first synthesis of the star-shaped polymer using calixarene derivatives. Calixarenes, such as $p$-t-butylcalix[8]arene (BCA), $p$-methylcalix[6]arene (MCA), and calix[4]resorcinarene (CRA), are cyclic oligomers with many hydroxy groups and can be used as the cores for the synthesis of star-shaped polymers. Furthermore, Sawamoto ${ }^{27}$ and Taton ${ }^{28}$ reported that the well-defined star shaped polymers with 4,6 , and 8 -arms were prepared by the core-first methods using the calixarene derivatives as multifunctional initiators.

About ten years ago, Nishikubo et al. ${ }^{29}$ have found novel ring-opening reaction of thiiranes with thioesters. This reaction proceeded smoothly and regioselectively in the presence of quaternary onium salts as catalysts to afford the corresponding thioesters in high yields. Furthermore, they achieved successful synthesis of the linear polysulfides by the acyl transfer polymerization of thiiranes with thioesters. ${ }^{30}$ In this reaction system, the continuous insertion reaction of thiiranes into thioester moieties proceeded in living like fashion, affording the corresponding polysulfides with narrow molecular weight distribution.

On the other hand, several reports concerning the physical properties of star shaped polymers, such as viscosities, solubilities, and thermal properties have been reported. ${ }^{25,31-35}$ However, no research has been reported the refractive-indices properties of the starshaped polymers.

${ }^{\dagger}$ To whom correspondence should be addressed (E-mail: nishikubot@kanagawa-u.ac.jp). 
From these above considerations, we examined here the syntheses and refractive-indices properties of new sulfur containing octa-arm star-shaped polymers with controlled the arm length by the insertion reaction of the $p$-t-butylcalix[8]arene-based octa(thioester)s with 3-phenoxypropyrene sulfide (PPS). Then, we found that the resulting star-shaped polymers have higher values of refractive indices compared to those of corresponding linear polymers.

\section{EXPERIMENTAL}

\section{Materials}

1-Methyl-2-pyrrolidone (NMP) and pyridine were dried with $\mathrm{CaH}_{2}$ and were purified by distillation before use. Tetrabutylammonium bromide (TBAB) was recrystallized from dried ethyl acetate. Tetrabutylammonium chloride (TBAC) and tetraphenylphosphonium chloride (TPPC) were used without further purification. Cesium carbonate $\left(\mathrm{Cs}_{2} \mathrm{CO}_{3}\right)$, potassium thioacetate, tetrahydrofuran (THF), 3-phenoxymethyloxirane, chloroacetylchloride, ethyl acetate, chloroform $\left(\mathrm{CHCl}_{3}\right)$ and $n$-hexane were used without further purification. $p$ - $t$-Butylcalix[8]arene (BCA[8]) (donated from Shin Nakamura Chemical, Co.) was recrystallized from THF.

\section{Measurements}

Infrared (IR) spectra were measured on a Jasco Model IR-420 spectrometer. The ${ }^{1} \mathrm{H}$ NMR spectra were recorded on JEOL Model JNM $\alpha-500(500 \mathrm{MHz}$ for ${ }^{1} \mathrm{H}$ NMR and $125 \mathrm{MHz}$ for ${ }^{13} \mathrm{C}$ NMR) instruments in $\mathrm{CDCl}_{3}$ and DMSO- $d_{6}$ using $\mathrm{Me}_{4} \mathrm{Si}$ (TMS) as an internal standard reagent for ${ }^{1} \mathrm{H}$ NMR. Matrix-assisted laser desorption ionization time-of-flight mass (MALDI-TOF-MS) experiments were performed SHIMADZU/KRATOS MALDI-TOF-MS using dihydroxy benzoic acid as matrix and chloroform as solvent. The number-average molecular weight $\left(M_{\mathrm{n}}\right)$ and weight-average molecular weight $\left(M_{\mathrm{w}}\right)$ of the polymers were estimated by gel permeation chromatography (GPC; TOSOH model HLC-8020) on TSK gel Multipore Hxl-M columns calibrated by narrow molecular weight polystyrene standards and with THF as an eluent without correction with a refractive index detector. The refractive-index (NOS) of the polymers with about $0.1 \mu \mathrm{m}$ on spin coating on silicon-wafers was measured by Ellipsometry at 0.6328 $\mu \mathrm{m}$ with a Gaertener Scientific. Co. model L116C ellipsometer.

\section{Synthesis of 3-Phenoxypropyrene Sulfide (PPS)}

To a solution of thiourea $(91.3 \mathrm{~g}, 1.2 \mathrm{~mol})$ in water ( $800 \mathrm{~mL}$ ) was added conc. $\mathrm{H}_{2} \mathrm{SO}_{4}(32 \mathrm{~mL}, 0.6 \mathrm{~mol})$ slowly to the resulting mixture, and then 3-phenoxy- methyloxirane $(150.2 \mathrm{~g}, 1.0 \mathrm{~mol})$ slowly at $0{ }^{\circ} \mathrm{C}$. The resulting mixture was stirred at $25^{\circ} \mathrm{C}$ for $24 \mathrm{~h}$. The reaction mixture became heterogeneous to obtain the colorless solid. The resulting solid was filtered off and then washed with ethyl ether to obtain the 2hydroxy-3-phenoxypropylthiulonium sulfonic acid $(\mathrm{HPT}) . \quad$ Yield $=243.4 \mathrm{~g} \quad(96 \%) . \quad \mathrm{mp}=165-166^{\circ} \mathrm{C}$. IR $(\mathrm{KBr}) ; v=3200(\mathrm{O}-\mathrm{H}), 1658(\mathrm{~N}-\mathrm{H}), 1248(\mathrm{C}-$ $\mathrm{O}-\mathrm{C}$ ether).

Next, to a solution of synthesized HPT $(51.5 \mathrm{~g}$, $0.2 \mathrm{~mol})$ in water $(300 \mathrm{~mL})$ was added $\mathrm{Na}_{2} \mathrm{CO}_{3}$ aqueous solution $(2 \mathrm{~mol} / \mathrm{L}, 100 \mathrm{~mL})$. The mixture was stirred at $60{ }^{\circ} \mathrm{C}$ for $2 \mathrm{~h}$. After that, $\mathrm{CHCl}_{3}(300 \mathrm{~mL})$ was added to the resulting mixture. The organic phase was dried over $\mathrm{MgSO}_{4}$ and concentrated by a rotary evaporator, followed by distillation to obtain colorless liquid PPS. $\mathrm{bp}=94.3^{\circ} \mathrm{C} / 1.7 \mathrm{mmHg}$. Yield $=17.2 \mathrm{~g}$ (52\%). ${ }^{1} \mathrm{H}$ NMR $\left(500 \mathrm{MHz}, \mathrm{CDCl}_{3}, \mathrm{TMS}\right) \delta(\mathrm{ppm})=$ $2.31,2.59$ (dd, $2.0 \mathrm{H}, J=5.4 \mathrm{~Hz}, J=6.0 \mathrm{~Hz},-\mathrm{CH}_{2}-$ $\mathrm{S}-$ ), 3.26 (q, $1.0 \mathrm{H}, J=7.2 \mathrm{~Hz},>\mathrm{CH}-\mathrm{S}$ ), 3.87-3.89, 4.12-4.21 (m, 2.0H, $\left.-\mathrm{O}-\mathrm{CH}_{2}-\right)$, 6.89-7.23 (m, 5.0H, aromatic $\mathrm{H}) \cdot{ }^{13} \mathrm{C} \mathrm{NMR}\left(126 \mathrm{MHz}, \mathrm{CDCl}_{3}, \mathrm{TMS}\right) \delta$ $(\mathrm{ppm})=23.8\left(-\mathrm{CH}_{2}-\mathrm{S}-\right), 31.4(>\mathrm{CH}-\mathrm{S}-), 72.3(-\mathrm{O}-$ $\mathrm{CH}_{2}-$ ), 114.5, 121.1, 129.4, and 158.3 (aromatic C).

Synthesis of p-t-Butylcalix[8]arene Derivative $O$ (Chloromethylcarbonyl)-tert-butylcalix[8]arene (BCACl)

To a solution of the $p$ - $t$-butylcalix[8]arene (BCA[8]) $(5.20 \mathrm{~g}, 32 \mathrm{mmol}$ as hydroxy groups) in THF $(100 \mathrm{~mL})$ were added pyridine $(7.59 \mathrm{~mL}, 96$ mmol), and then a solution of chloroacetylchloride $(7.39 \mathrm{~g}, 30 \mathrm{mmol})$ slowly at $0{ }^{\circ} \mathrm{C}$ under nitrogen. The mixture was stirred at room temperature for $24 \mathrm{~h}$. The resulting mixture was concentrated by a rotary evaporator. After that, ethylacetate $(200 \mathrm{~mL})$ was added to the residual mass and the resulting suspension was washed with water, saturated aqueous sodium hydrogen carbonate, and water. The organic phase was dried over $\mathrm{MgSO}_{4}$ and concentrated by a rotary evaporator. The residue was washed with hexane several times, followed by recrystallization from the mix solvents with $\mathrm{MeOH}$ and THF to obtain the colorless solid (BCA-Cl). Yield $=7.0 \mathrm{~g}(91 \%)$. IR (neat); $v=$ 2958 (C-H aliphatic), 1777 ( $\mathrm{C}=\mathrm{O}$ ester), 1596 and $1479\left(\mathrm{C}=\mathrm{C}\right.$ aromatic). ${ }^{1} \mathrm{H}$ NMR $\left(500 \mathrm{MHz}, \mathrm{CDCl}_{3}\right.$, TMS $\delta(\mathrm{ppm})=1.18\left(\mathrm{~s}, 72.0 \mathrm{H},-\left(\mathrm{CH}_{3}\right)_{3}\right), 3.44-3.79$ $\left(\mathrm{m}, 32.0 \mathrm{H}, \mathrm{Cl}-\mathrm{CH}_{2}-\right.$ and $\left.\mathrm{ph}-\mathrm{CH}_{2}-\mathrm{Ph}\right)$. MALDI TOFMS $m / z(\mathrm{M}+\mathrm{Na})^{+}$Calcd. for $\left(\mathrm{C}_{104} \mathrm{H}_{120} \mathrm{C}_{18} \mathrm{O}_{16}+\right.$ $\mathrm{Na})$ : 1932.68. Found: 1932.67.

Synthesis of Calixarene-core Initiator O-(Benzoylthiomethylcarbonyl)-t-butylcalix[8]arene (BCA[8]-core) Containing Octa-Thioesters

The mixture of potassium thioacetate $(2.0 \mathrm{~g}$, 
$10.0 \mathrm{mmol})$ and BCA-Cl (4.77 g, $2.5 \mathrm{mmol})$ was stirred in the presence of TBAB $(0.07 \mathrm{~g}, 0.21 \mathrm{mmol})$ in NMP $(10 \mathrm{~mL})$ at room temperature for $24 \mathrm{~h}$. After that, potassium thioacetate $(2.0 \mathrm{~g}, 10.0 \mathrm{mmol})$ added to the resulting solution, and then the mixture was stirred at $50{ }^{\circ} \mathrm{C}$ for $24 \mathrm{~h}$. The resulting mixture was concentrated by a rotary evaporator. The organic phase was dried over $\mathrm{MgSO}_{4}$ and concentrated by a rotary evaporator. The residue was purified by silica gel column chromatography eluted with ethyl acetate/ hexane (volume ratio 1/1) to obtain the yellow solid (BCA[8]-core). Yield $=3.95 \mathrm{~g} \quad(58 \%) . \quad \mathrm{mp}=147-$ $148^{\circ} \mathrm{C}$. IR (neat); $v=2962(\mathrm{C}-\mathrm{H}$ aliphatic), 1758 $(\mathrm{C}=\mathrm{O}$ ester $), 1669(\mathrm{C}=\mathrm{O}$, thioester $), 1596$ and 1480 $(\mathrm{C}=\mathrm{C}$ aromatic $), 1128(\mathrm{C}-\mathrm{O}-\mathrm{C}$, ether $), 755(\mathrm{C}-\mathrm{S}-\mathrm{C}$, sulfide). ${ }^{1} \mathrm{H} \mathrm{NMR}\left(500 \mathrm{MHz}, \mathrm{CDCl}_{3}, \mathrm{TMS}\right) \delta(\mathrm{ppm})=$ 0.95 (broad s, $\left.72.0 \mathrm{H},-\left(\mathrm{CH}_{3}\right)_{3}\right), 2.94-4.32(\mathrm{~m}, 32.0 \mathrm{H}$, $-\mathrm{S}-\mathrm{CH}_{2}-$ and ph- $\left.\mathrm{CH}_{2}-\mathrm{Ph}\right), 5.80-8.00(\mathrm{~m}, 40.0 \mathrm{H}$, aromatic H). ${ }^{1} \mathrm{H}$ NMR $\left(500 \mathrm{MHz}\right.$, DMSO- $d_{6}$, TMS) $\delta(\mathrm{ppm})=0,94\left(\right.$ broad $\left.\mathrm{m}, 72.0 \mathrm{H},-\left(\mathrm{CH}_{3}\right)_{3}\right), 3.69$ (broad s, $16.0 \mathrm{H},-\mathrm{S}-\mathrm{CH}_{2}-$ ), 2.31 (broad s, $16.0 \mathrm{H}$, ph- $\left.\mathrm{CH}_{2}-\mathrm{Ph}\right), 7.10-7.79(\mathrm{~m}, 40.0 \mathrm{H}$, aromatic $\mathrm{H})$. MALDI TOF-MS $m / z \quad(\mathrm{M}+\mathrm{Na})^{+}$Calcd. for $\left(\mathrm{C}_{160} \mathrm{H}_{160} \mathrm{O}_{24} \mathrm{~S}_{8}+\mathrm{Na}\right):$ 2762.57. Found: 2761.65 . Anal. Calcd. for $\mathrm{C}_{160} \mathrm{H}_{160} \mathrm{O}_{24} \mathrm{~S}_{8}$ Calcd. C $70.56 \mathrm{H}$ 5.92 Found C 70.57H 5.72.

Syntheis of Octa-Arms Star-Shaped Polysulfides poly$\left(P P S_{(n)}-B C A[8]_{\text {core }}\right)$ Radiating from p-t-Butylcalix[8]arene Core

A typical procedure for the reaction of insertion reaction of excess PPS into BCA[8]-core was as follows: BCA[8]-core $(0.054 \mathrm{~g}, 0.16 \mathrm{mmol}$ as thioester groups), PPS (1.064 g, $6.4 \mathrm{mmol})$, and TBAC (0.003 g, $0.16 \mathrm{mmol})$ were dissolved in NMP $(0.25 \mathrm{~mL})$ in a polymerization tube. The tube was cooled, degassed, and sealed off, and then the reaction was carried out at $90^{\circ} \mathrm{C}$ for $24 \mathrm{~h}$. The reaction mixture was diluted by the addition of THF and poured into methanol to precipitate a polymer; it was reprecipitated twice from THF into methanol and dried in vacuo at $60^{\circ} \mathrm{C}$ for $24 \mathrm{~h}$. The yield of poly $\left(\operatorname{PPS}_{(n)}-\mathrm{BCA}[8]\right) \quad(n=40)$ was $85 \%(0.95 \mathrm{~g}) . M_{\mathrm{n}}=12000$ and $M_{\mathrm{w}} / M_{\mathrm{n}}=1.70$. IR (neat); $v=2964(\mathrm{C}-\mathrm{H}$, aliphatic), $1735(\mathrm{C}=\mathrm{O}$, ester), $1662(\mathrm{C}=\mathrm{O}$, thioester $), 1598$ and $1496(\mathrm{C}=\mathrm{C}$, aromatic), $754(\mathrm{C}-\mathrm{S}-\mathrm{C}) .{ }^{1} \mathrm{H} \mathrm{NMR}\left(500 \mathrm{MHz}, \mathrm{CDCl}_{3}\right.$, TMS) $\delta(\mathrm{ppm})=1.05\left(\right.$ broads $\left.\mathrm{s}, 9 \mathrm{H},-\mathrm{C}\left(\mathrm{CH}_{3}\right)_{3}\right)$, $3.00-3.22\left(\mathrm{~m}, \quad 119.9 \mathrm{H}, \quad \mathrm{S}-\mathrm{CH}_{2}-\mathrm{CH}<\right), \quad 4.06-4.12$ $\left(\mathrm{m}, 119.9 \mathrm{H}, \mathrm{Ph}-\mathrm{CH}_{2}-\mathrm{Ph}\right.$ of BCA moieties, $-\mathrm{C}(\mathrm{O})-$ $\mathrm{CH}_{2}-\mathrm{S}$, and $\left.-\mathrm{CH}_{2}-\mathrm{O}-\mathrm{Ph}\right), 6.83-7.89(\mathrm{~m}, 207.4 \mathrm{H}$, aromatic $\mathrm{H})$.

Synthesis of 1-t-Butyl-4-benzoylthiomethylcarbonyloxybenzene (Bphe)

Bphe was synthesized from $p$ - $t$-butylphenol $(4.81 \mathrm{~g}$,
$32 \mathrm{mmol})$, chloroacetylchloride $(7.39 \mathrm{~g}, 30 \mathrm{mmol})$, and thioacetate $(12.0 \mathrm{~g}, 60.0 \mathrm{mmol})$ in the similar way as BCA[8]-core as mentioned above, and purified by silica gel column chromatography eluted with ethylacetate $/ n$-hexane (volume ratio $1 / 1$ ) to obtain the colorless solid. Yield $=3.6 \mathrm{~g}(34.2 \%) .{ }^{1} \mathrm{H}$ NMR $(500 \mathrm{MHz}$, DMSO- $d_{6}$, TMS $) \delta(\mathrm{ppm})=1.25\left(\mathrm{~s}, 9 \mathrm{H},-\mathrm{C}\left(\mathrm{CH}_{3}\right)_{3}\right)$, $4.26\left(\mathrm{~s}, 2.0 \mathrm{H}, \mathrm{S}-\mathrm{CH}_{2}-\right), 7.05-7.98(\mathrm{~m}, 9.0 \mathrm{H}$, aromatic H). ${ }^{13} \mathrm{C}$ NMR $\left(125 \mathrm{MHz}\right.$, DMSO- $d_{6}$, TMS $) \delta(\mathrm{ppm})=$ $31.10\left(\mathrm{CH}_{3}-\right), 31.33$ (quaternary carbon), $34.16(\mathrm{~S}-\mathrm{C}-$ $\mathrm{C}(\mathrm{O})-), 120.84,126.27,126.99,129.23,134.36$, $135.48,148.22$, and 148.37 (aromatic carbon), 167.62 (-C(O)-O), 190. 17 (-C(O)-S-).

Synthesis of Linear Polysulfides Poly $\left(P P S_{(n)}\right.$-Bphe) by the Insertion Reaction of PPS into Bphe

The insertion reaction of excess PPS $(1.064 \mathrm{~g}, 6.4$ $\mathrm{mmol})$ into Bphe $(2.10 \mathrm{~g}, 6.4 \mathrm{mmol}$ as thioester moieties) in the presence of TBAC $(0.003 \mathrm{~g}, 0.16 \mathrm{mmol})$ was performed in the similar way as the synthesis of poly( $\left.\operatorname{PPS}_{(n)}-\mathrm{BCA}[8]_{\text {core }}\right)$ as mentioned above, and it was reprecipitated twice from THF into methanol and dried in vacuo at $60^{\circ} \mathrm{C}$ for $24 \mathrm{~h}$. The yield of poly(PPS $(n)$-BPhe) $(n=40)$ was $85 \%(0.95 \mathrm{~g}) . M_{\mathrm{n}}=$ 12000 and $M_{\mathrm{w}} / M_{\mathrm{n}}=1.70$. IR (neat); $v=2964(\mathrm{C}-$ $\mathrm{H}$, aliphatic $), 1735(\mathrm{C}=\mathrm{O}$, ester $), 1662(\mathrm{C}=\mathrm{O}$, thioester), 1598 and $1496(\mathrm{C}=\mathrm{C}$, aromatic), $754(\mathrm{C}-\mathrm{S}-\mathrm{C})$. ${ }^{1} \mathrm{H}$ NMR $\left(500 \mathrm{MHz}\right.$, DMSO- $d_{6}$, TMS $) \delta(\mathrm{ppm})=$ 1.05 (broads s, $\left.9 \mathrm{H},-\mathrm{C}\left(\mathrm{CH}_{3}\right)_{3}\right), 3.00-3.22(\mathrm{~m}, 119.9 \mathrm{H}$, $\left.\mathrm{S}-\mathrm{CH}_{2}-\mathrm{CH}<\right), 4.06-4.12\left(\mathrm{~m}, 119.9 \mathrm{H}, \mathrm{Ph}-\mathrm{CH}_{2}-\mathrm{Ph}\right.$ of BCA moieties, $-\mathrm{C}(\mathrm{O})-\mathrm{CH}_{2}-\mathrm{S}$, and $\left.-\mathrm{CH}_{2}-\mathrm{O}-\mathrm{Ph}\right)$, 6.83-7.89 (m, 207.4H, aromatic $\mathrm{H})$.

\section{Hydrolysis Degradation Reaction $\operatorname{Poly}\left(P P S_{(n)}{ }^{-}\right.$ $B C A_{\text {core }}$ )}

The solution of poly $\left(\mathrm{PPS}_{70}-\mathrm{BCA}[8]_{\text {core }}\right) \quad\left(M_{\mathrm{n}}=\right.$ 22600, $M_{\mathrm{w}} / M_{\mathrm{n}}=1.74$, run 9 in Table I) $(0.45 \mathrm{~g})$ and $\mathrm{KOH}(0.1 \mathrm{~g}, 1.78 \mathrm{mmol})$ in the mixture of THF and water $(\mathrm{THF} /$ water $=5 \mathrm{~mL} / 1 \mathrm{~mL})$ was stirred at $70^{\circ} \mathrm{C}$ for $24 \mathrm{~h}$. After that, the resulting solution was concentrated by a rotary evaporator. The resulting residue was poured into large amount of $\mathrm{MeOH}$ to precipitate the polymer, it was reprecipitated twice from THF into methanol and dried in vacuo at $60^{\circ} \mathrm{C}$ for $24 \mathrm{~h}$. Next, the obtained product was dissolved in NMP, and the mixture was stirred at $25^{\circ} \mathrm{C}$ for 30 min. After that, $p$ - $t$-butylbenzylchloride $(0.03 \mathrm{~g}, 0.16$ mmol) added to the resulting solution, and then stirred at $25^{\circ} \mathrm{C}$ for $24 \mathrm{~h}$. The resulting mixture was poured into large amount of $\mathrm{MeOH}$ to precipitate the polymer, it was reprecipitated twice from THF into methanol and dried in vacuo at $60^{\circ} \mathrm{C}$ for $24 \mathrm{~h}$. The yield was $56 \%(0.10 \mathrm{~g}) . M_{\mathrm{n}}=7200$ and $M_{\mathrm{w}} / M_{\mathrm{n}}=1.89$. IR (neat); $v=2925(\mathrm{C}-\mathrm{H}$, aliphatic), 1598 and 1496 $\left(\mathrm{C}=\mathrm{C}\right.$, aromatic), $754(\mathrm{C}-\mathrm{S}-\mathrm{C}) .{ }^{1} \mathrm{H}$ NMR $(500 \mathrm{MHz}$, 
H. KUDO et al.

Table I. The continuous insertion reaction of PPS with BCA[8] $]^{\mathrm{a}}$

\begin{tabular}{|c|c|c|c|c|c|c|c|}
\hline \multirow[t]{2}{*}{ Run } & Feed Molar Ratio & \multirow[t]{2}{*}{$\begin{array}{l}\text { Yield } \\
(\%)^{\mathrm{b}}\end{array}$} & Polymer Composition ${ }^{c}$ & \multirow[t]{2}{*}{$\begin{array}{c}M_{\mathrm{n}, \mathrm{SEC}}{ }^{\mathrm{d}} \\
\left(M_{\mathrm{w}} / M_{\mathrm{n}}\right)\end{array}$} & \multirow[t]{2}{*}{$M_{\mathrm{n}, \mathrm{NMR}}{ }^{\mathrm{e}}$} & \multirow[t]{2}{*}{$n_{\mathrm{D}}^{\mathrm{f}}$} & \multirow[t]{2}{*}{$\begin{array}{l}\text { Sulfur Content } \\
(\%)\end{array}$} \\
\hline & $\mathrm{PPS} /(\mathrm{BCA}[8]$-core $\times 8)$ & & $\mathrm{PPS} /(\mathrm{BCA}[8]$-core $\times 8)$ & & & & \\
\hline 1 & $5 / 1$ & 89 & $5 / 1$ & $3200(1.59)$ & 9400 & 1.619 & 16.4 \\
\hline 2 & $10 / 1$ & 90 & $10 / 1$ & $5700(1.64)$ & 15900 & 1.623 & 17.6 \\
\hline 3 & $15 / 1$ & 90 & $15 / 1$ & $6000(1.63)$ & 22700 & 1.626 & 18.1 \\
\hline 4 & $20 / 1$ & 89 & $20 / 1$ & $6200(1.65)$ & 29800 & 1.631 & 18.3 \\
\hline 5 & $30 / 1$ & 92 & $30 / 1$ & $11000(1.63)$ & 42300 & 1.636 & 18.6 \\
\hline 6 & $40 / 1$ & 85 & $40 / 1$ & $12000(1.70)$ & 60000 & 1.639 & 18.8 \\
\hline 7 & $50 / 1$ & 91 & $50 / 1$ & $22600(1.72)$ & 69100 & 1.639 & 18.9 \\
\hline 8 & $60 / 1$ & 84 & $60 / 1$ & $23600(1.77)$ & 82400 & 1.639 & 18.9 \\
\hline 9 & $70 / 1$ & 93 & $70 / 1$ & $22600(1.74)$ & 95700 & 1.639 & 18.9 \\
\hline
\end{tabular}

${ }^{a}$ The reaction of PPS and BCA[8]-core was carried out in the presence of TBAC as a catalyst in NMP at $90^{\circ} \mathrm{C}$ for $24 \mathrm{~h}$. ${ }^{\mathrm{b}}$ Methanol-insoluble parts. ${ }^{\mathrm{c}}$ Determined by ${ }^{1} \mathrm{H}$ NMR. ${ }^{\mathrm{d}}$ Estimated by SEC based on polystyrene standards; eluent: THF. ${ }^{\mathrm{e}} \mathrm{Calculated}$ by ${ }^{1} \mathrm{H}$ NMR. ${ }^{\mathrm{f}}$ Average values of refractive-indices determined by ellipsometer using $0.6328 \mu \mathrm{m}$.

DMSO- $\left.d_{6}, \mathrm{TMS}\right) \delta(\mathrm{ppm})=1.19($ broad $\mathrm{s}, 18 \mathrm{H}$, $\left.-\mathrm{C}\left(\mathrm{CH}_{3}\right)_{3}\right), 3.00-3.29\left(\mathrm{~m}, 210.4 \mathrm{H}, \mathrm{S}-\mathrm{CH}_{2}-\mathrm{CH}<\right)$, 4.04-4.12 (m, $142.4 \mathrm{H},-\mathrm{CH}_{2}-$ of BCA, $-\mathrm{C}(\mathrm{O})-\mathrm{CH}_{2}-$ $\mathrm{S}-$, and $\left.-\mathrm{CH}_{2}-\mathrm{O}-\mathrm{Ph}\right)$.

\section{Refractive-Index $\left(n_{D}\right)$ of the Star-Shaped Polysulfide}

THF solutions of the star-shaped polysulfides were prepared, followed by spin-coating on a silicon-wafer and dried in vacuo at $25^{\circ} \mathrm{C}$ for $24 \mathrm{~h}$. Then, $n_{\mathrm{D}}$ 's of the obtained films with about $0.1 \mu \mathrm{m}$ spin-coated on silicon-wafer were determined by elipsometry at $632.8 \mathrm{~nm}$.

\section{RESULTS AND DISCUSSION}

Synthesis of Calixarene-core with Octa(thioester)s (BCA[8]-core)

The calixarene-core with octa(thioester)s (BCA[8]core) was synthesized from $p$-t-butylcalix[8]arene (BCA[8]) (Scheme 1). BCA[8] derivative BCA[8]$\mathrm{Cl}$ was prepared by the reaction of $\mathrm{BCA}$ with chloroacetylchloride in the presence of pyridine in THF at room temperature for $24 \mathrm{~h}$. Furthermore, calixarenecore with octa-thioeters BCA[8]-core was obtained from the reaction of $\mathrm{BCA}[8]-\mathrm{Cl}$ with potassium thioacetate in the presence of TBAB as a phase transfer catalyst in NMP. The structures of these compounds were confirmed by IR, and ${ }^{1} \mathrm{H}$ NMR spectroscopy, besides MALDI-TOF mass spectroscopy and elemental analysis.

Synthesis of Octa-Arms Star-Shaped Polysulfides Radiating from p-t-Butylcalix[8]arene Core

The insertion reaction of excess PPS into BCA[8]core was examined in the presence of tetrabutylammoniumchloride (TBAC) as a catalyst at $90^{\circ} \mathrm{C}$ for $24 \mathrm{~h}$ in NMP with various feed monomer molar ratios (Scheme 2). In all cases, the reaction mixtures were consistently homogeneous with products remaining in the solutions. The resulting polymers poly $\left(\mathrm{PPS}_{(n)^{-}}\right.$ $\left.\mathrm{BCA}[8]_{\text {core }}\right)(n=5,10,15,20,30,40,50,60,70)$ were isolated by precipitation with methanol in 8491\% yields as summarized in Table I.

The structures of $\operatorname{poly}\left(\mathrm{PPS}_{(n)}-\mathrm{BCA}[8]_{\text {core }}\right)$ were confirmed by IR and ${ }^{1} \mathrm{H}$ NMR spectroscopy. Figure 1 illustrates the ${ }^{1} \mathrm{H}$ NMR spectrum of $\operatorname{poly}\left(\operatorname{PPS}_{(n)^{-}}\right.$ BCA $\left.[8]_{\text {core }}\right)\left(n=40, M_{\mathrm{n}}=12000, M_{\mathrm{w}} / M_{\mathrm{n}}=1.70\right.$, run 6 in Table I) along with that of $\mathrm{BCA}[8]$-core. This figure shows signals assignable to methyl groups $\left(-\mathrm{C}\left(\mathrm{CH}_{3}\right)_{3}\right)$ of $\mathrm{BCA}[8]$ and methylene protons $\left(>\mathrm{CH}_{2}-\mathrm{O}-\right)$ of PPS at 1.05 and $4.06-4.13 \mathrm{ppm}$, respectively.

In the IR spectrum of this polymer, characteristic absorption peaks were observed at 1735,1662 , and $754 \mathrm{~cm}^{-1}$ due to $\mathrm{C}=\mathrm{O}$ of ester, $\mathrm{C}=\mathrm{O}$ of thioester, and $\mathrm{C}-\mathrm{S}-\mathrm{C}$, respectively. These results showed that poly $\left(\operatorname{PPS}_{(n)}-\mathrm{BCA}[8]_{\text {core }}\right)$ had the structure composed from eight-arms polysulfide units and $p$-t-butylcalix[8]arene core as shown in Scheme 2. In this study, we could calculate the degree of polymerization of PPS (DE) by the ${ }^{1} \mathrm{H}$ NMR integration of the signals for methyl protons $\left(-\mathrm{C}\left(\mathrm{CH}_{3}\right)_{3}\right)$ of $\mathrm{BCA}[8]$ and methylene protons $\left(>\mathrm{CH}_{2}-\mathrm{O}-\right)$ of PPS. In all cases, the DEs of poly $\left(\mathrm{PPS}_{(n)}-\mathrm{BCA}[8]_{\text {core }}\right)$ were the same with feed molar ratios of PPS; that is the length of the arms of poly(PPS $\left.(n)-\mathrm{BCA}[8]_{\text {core }}\right)$ could be controlled.

Furthermore, the relationships between the $M_{\mathrm{n}} \mathrm{s}$ and feed molar ratios of PPS $/(\mathrm{BCA}[8] \times 8)$ were illustrated in Figure 2. The linear relationships between $M_{\mathrm{n}, \mathrm{SEC}} \mathrm{S}$ estimated by $\mathrm{SEC}, M_{\mathrm{n}, \mathrm{NMR}} \mathrm{S}$ calculated by ${ }^{1} \mathrm{H}$ NMR and feed molar ratios of PPS were found respectively. The values of SEC for star-shaped polymers were lower than those of ${ }^{1} \mathrm{H}$ NMR, since hydrodynamic volumes of star-shaped polymer are smaller than those of polystyrene standards used for calibrations. Consequently, the well-defined star-shaped 


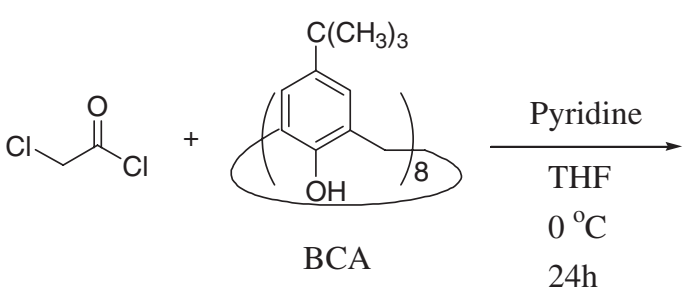

$24 \mathrm{~h}$<smiles>CC(C)(C)CC12Cc3cc(C(C)(C)C)cc(c3C1)C2</smiles>

$\mathrm{BCA}-\mathrm{Cl}$<smiles>O=C(O)c1ccccc1</smiles>

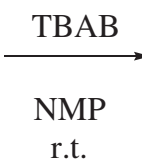<smiles>CC(C)(C)c1cc2c(OC(=O)CSC(=O)c3ccccc3)c(c1)CC1CCC(C2)C1</smiles>

$\mathrm{BCA}[8]$-core

Scheme 1.<smiles>Brc1ccc(OCC2CS2)cc1</smiles>
PPS<smiles>CC1(C)Cc2cc(C(C)(C)C)cc3c2OC(CC(=O)CSC(=O)c2ccccc2)(C3)C1</smiles>

BCA[8]-core

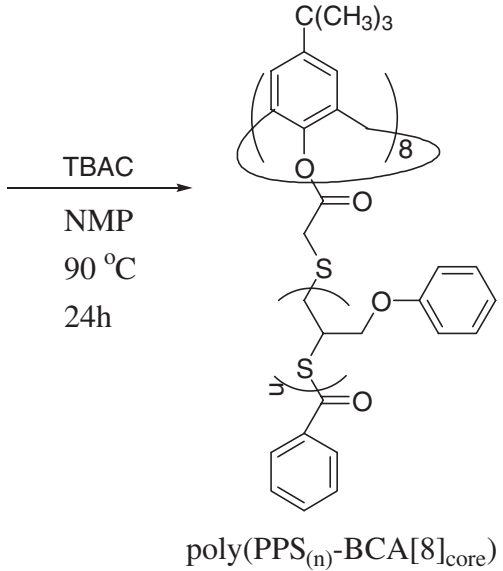

$\mathrm{n}=5,10,15,20,30,40,50,60,70$

Scheme 2.

polysulfides with certain length of eight-arms could be obtained by the continuous insertion reaction of PPS into $\mathrm{BCA}[8]$-core in high yields.

Refractive-indices $\left(n_{D} s\right)$ of the Octa-Arms Star-Shaped Polysulfides

A THF solution of the polymers was prepared, and this was followed by spin coating on a silicon wafer and dried in vacuo at room temperature for $3 \mathrm{~h}$. The refractive-indices of thin polymer layers $(c a .0 .1 \mu \mathrm{m})$ were determined by ellipsometry indices. These results were also summarized in Table I. The relationship between $n_{\mathrm{D}}$ and $M_{\mathrm{n}, \mathrm{NMR}}$ was also illustrated in Figure 3A. This result shows that the $n_{\mathrm{D}}$ increased up to $M_{\mathrm{n}, \mathrm{NMR}}=6,000$ of the $\operatorname{poly}\left(\mathrm{PPS}_{(n)}-\mathrm{BCA}[8]_{\text {core }}\right)$.
However, after that, constant $n_{\mathrm{D}}$ was obtained in the dependent of $M_{\mathrm{n}, \mathrm{NMR}} \mathrm{s}$. This means that the sulfur content ratios of the obtained star-shaped polymers increase with $M_{\mathrm{n}}$ to give maxima in $M_{\mathrm{n}, \mathrm{NMR}}=6000$. Figure 3B depicts the relationship between the refractive-indices $\left(n_{\mathrm{D}} \mathrm{s}\right)$ and sulfur contents of $\operatorname{poly}\left(\mathrm{PPS}_{(n)}{ }^{-}\right.$ $\left.\mathrm{BCA}[8]_{\text {core }}\right)$. It was observed that $n_{\mathrm{D}} \mathrm{s}$ increased with the values of sulfur contents. In this octa-arms starshaped polymer, the maximum ratio of sulfur-contents is about 18.9. Therefore, $n_{\mathrm{D}}=1.639$ is largest refractive-index value of this polymer. These results show that the refractive-indices values of the star-shaped polymers based on calixarenes can be controlled by the continuous insertion reaction of PPS into thioester groups. We also examined the synthesis and refrac- 

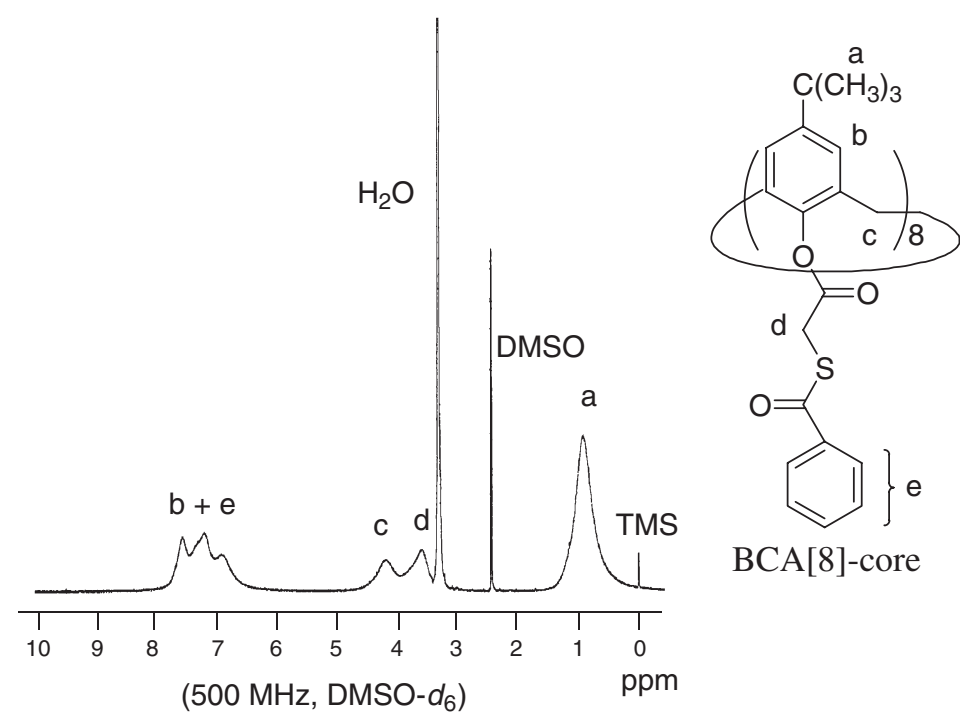

$\mathrm{BCA}[8]$-core
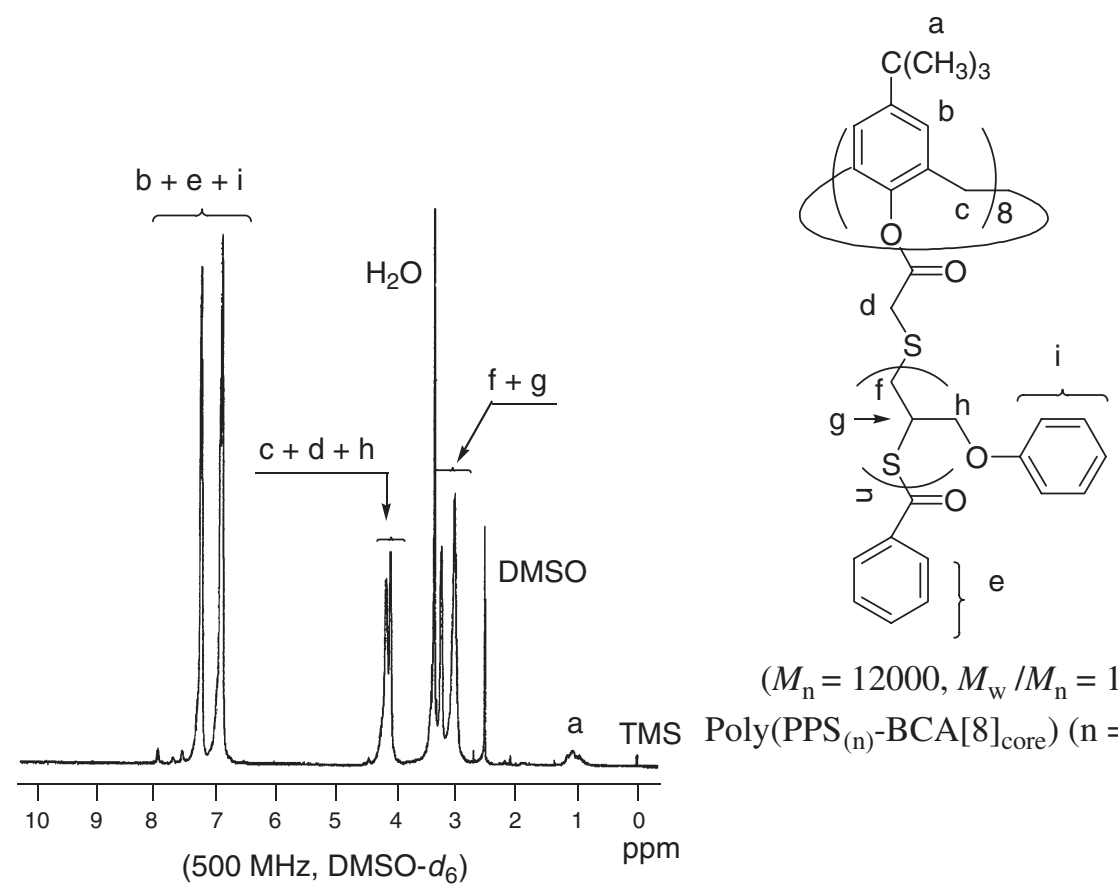

$$
\left(M_{\mathrm{n}}=12000, M_{\mathrm{w}} / M_{\mathrm{n}}=1.70\right)
$$

$\operatorname{Poly}\left(\mathrm{PPS}_{(\mathrm{n})}-\mathrm{BCA}[8]_{\text {core }}\right)(\mathrm{n}=40)$

Figure 1. ${ }^{1} \mathrm{H}$ NMR spectra of calixarene-core initiator with octa(thioester)s BCA[8]-core and poly $\left(\mathrm{PPS}_{(n)}-\mathrm{BCA}[8]_{\text {core }}\right)(n=40$, $M_{\mathrm{n}}=12000, M_{\mathrm{w}} / M_{\mathrm{n}}=1.70$, run 6 in Table I) obtained by the insertion reaction of PPS into BCA[8]-core.

tive-indices properties of the linear polymers poly$\left(\mathrm{PPS}_{(n)}\right.$-Bphe) which has almost the same skeletons as the star-shaped polymers (Scheme 3). The continuous insertion reaction of PPS and Bphe was carried out using TBAC as a catalyst at $90^{\circ} \mathrm{C}$ in NMP for $24 \mathrm{~h}$ in the various feed molar ratios of PPS/Bphe ( $n=10-90)$, affording corresponding polymers poly$\left(\mathrm{PPS}_{(n)}\right.$-Bphe) with $M_{\mathrm{n}, \mathrm{SEC}}$ in the range between 2000 and 15200 in good yields. These conditions and results were summarized in Table II. As mentioned previously, the values of SEC for star-shaped polymers were lower than those of ${ }^{1} \mathrm{H}$ NMR due to the effect of hydrodynamic volumes of star-shaped polymer. However, in the case of linear polysulfides poly $\left(\mathrm{PPS}_{(n)}{ }^{-}\right.$ Bphe), it was observed that the values of $M_{\mathrm{n}, \mathrm{SEC}}$ of
poly($\left(\mathrm{PPS}_{(n)}\right.$-Bphe) were good agree with those of $M_{\mathrm{n}, \mathrm{NMR}}$. Furthermore, poly $\left(\mathrm{PPS}_{(n)}-\mathrm{Bphe}\right)(n=10-40)$ were viscous liquid at room temperature and didn't have good film forming properties. Therefore, $n_{\mathrm{D}} \mathrm{s}$ of these linear polymers could not be determined by ellipsometry in the film state. However, the corresponding $\operatorname{poly}\left(\mathrm{PPS}_{(n)}\right.$-Bphe $)$ with $M_{\mathrm{n}, \mathrm{SEC}}=8300-15200$ $(n \geq 50)$ had good film-forming properties, and their $n_{\mathrm{D}} \mathrm{S}$ could be determined by ellipsometry. It was observed that $n_{\mathrm{D}} \mathrm{S}$ of the obtained poly( $\operatorname{PPS}_{(n)}$-Bphe)s ( $n=50,60,70,80$, and 90) were in the range between 1.612 and 1.614 , because of their sulfur-content ratios of poly(PPS ${ }_{(n)}$-Bphe)s $(n \geq 50)$ were almost the same to be $18.9 \%$. On the other hand, $n_{\mathrm{D}} \mathrm{s}$ of star-shaped polysulfides poly($\left(\mathrm{PPS}_{(n)}-\mathrm{BCA}[8]_{\text {core }}\right)$ with sulfur-con- 
tent ratio $=18.9 \%\left(M_{\mathrm{n}} \mathrm{s}=69100-95700\right.$, runs 7-9 in Table I) were 1.639. These results mean that $n_{\mathrm{D}}$ of star-shaped polymer poly $\left(\operatorname{PPS}_{(n)}-\mathrm{BCA}[8]_{\text {core }}\right)$ was larger than that of corresponding linear polymer poly$\left(\mathrm{PPS}_{(n)}-\mathrm{Bphe}\right)$, because of that star-shaped polymer had compact structure and high segment density compared to those of linear one. Furthermore, to confirm the hypothesis as mentioned above, the hydrolysis reaction of $\operatorname{poly}\left(\mathrm{PPS}_{(n)}-\mathrm{BCA}[8]_{\text {core }}\right)(n=70)$ was performed using $\mathrm{KOH}$ in the mix solution of THF and water at $70^{\circ} \mathrm{C}$ for $24 \mathrm{~h}$, followed by the reaction with $p$-t-butylbenzyl chloride at room temperature for $24 \mathrm{~h}$ to give the corresponding linear polysulfide poly$\left(\mathrm{PPS}_{70}\right)$ with $M_{\mathrm{n}}=7200, M_{\mathrm{w}} / M_{\mathrm{n}}=1.89$ in $56 \%$ yield (Scheme 4). The $M_{\mathrm{n}, \mathrm{SEC}}$ of poly $\left(\mathrm{PPS}_{70}\right)$ was not agree with that of linear polysulfide poly( $\left.\mathrm{PPS}_{(70)}-\mathrm{Bphe}\right)$. However, the molecular weight calculated by ${ }^{1} \mathrm{H}$ NMR of poly $\left(\mathrm{PPS}_{70}\right)$ was 11000 , which corresponded with that $\left(M_{\mathrm{n}, \mathrm{NMR}}=12000\right)$ of poly $\left(\mathrm{PPS}_{(70)}\right.$-Bphe $)$.

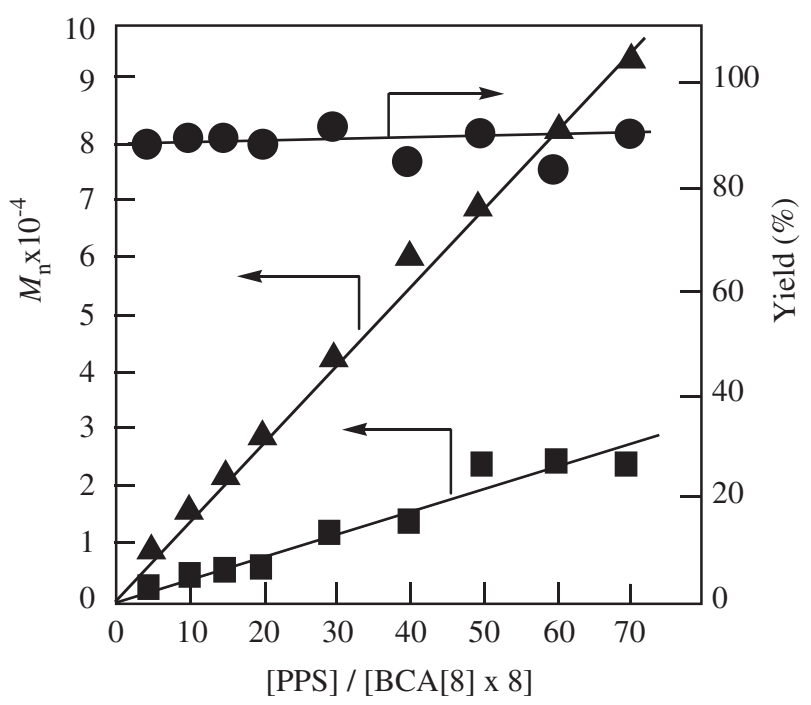

Figure 2. The relationships between $M_{\mathrm{n}, \mathrm{SEC}}$ estimated by SEC, $M_{\mathrm{n}, \mathrm{NMR}}$ calculated by ${ }^{1} \mathrm{H} \mathrm{NMR}$, polymer yields, and feed ratios of $[\mathrm{PPS}] /[(\mathrm{BCA}[8]$-core $) \times 8]$ on the continuous insertion

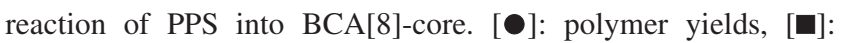
$M_{\mathrm{n}, \mathrm{SEC}},[\mathbf{\Delta}]: M_{\mathrm{n}, \mathrm{NMR}}$.
The sulfur contents of these obtained polymers, poly(PPS $\left.(n)-\mathrm{BCA}[8]_{\text {core }}\right)(n=70)$, poly($\left(\mathrm{PPS}_{(n)}\right.$-Bphe) $(n=70)$, and poly $\left(\mathrm{PPS}_{70}\right)$ were all the same to be $18.9 \%$. However, the $n_{\mathrm{D}} \mathrm{S}$ of poly $\left(\operatorname{PPS}_{(n)}-\mathrm{BCA}[8]_{\text {core }}\right)$ $(n=70)$, poly $\left(\operatorname{PPS}_{(n)}-\mathrm{Bphe}\right) \quad(n=70)$, and poly$\left(\mathrm{PPS}_{70}\right)$ were $1.639,1.614$, and 1.616 , respectively.

[A]

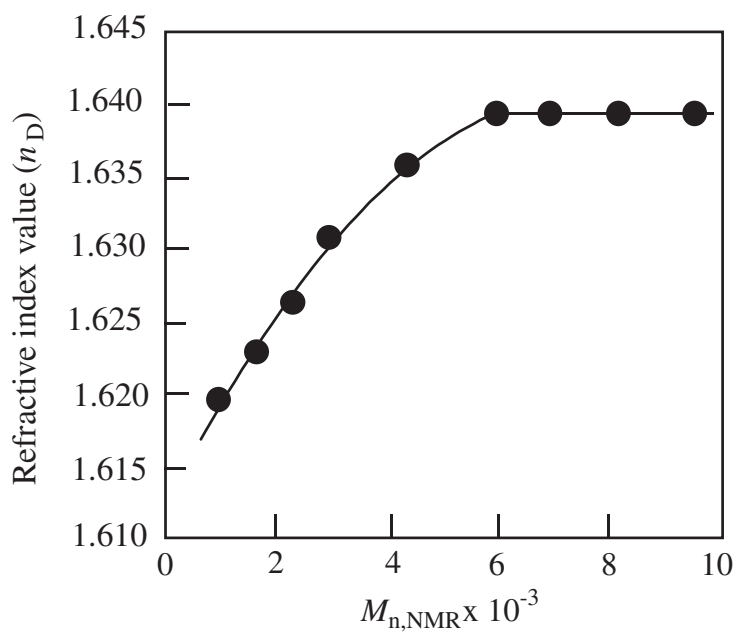

[B]

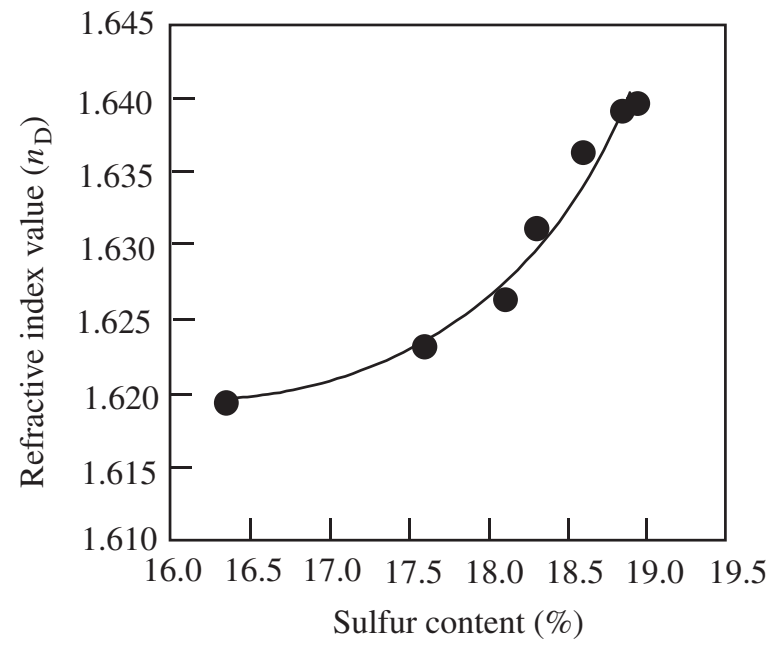

Figure 3. $[\mathrm{A}]$ The relationships between the refractive-indices values and $M_{\mathrm{n}, \mathrm{NMR}}$ of the poly $\left(\mathrm{PPS}_{(n)}-\mathrm{BCA}[8]_{\text {core }}\right)$. [B] The relationships between the refractive-indices values and sulfur contents of the poly $\left(\operatorname{PPS}_{(n)}-\mathrm{BCA}[8]_{\text {core }}\right)$.

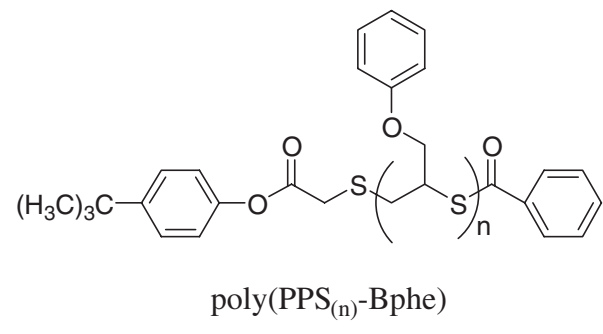

$\mathrm{n}=10,20,30,40,50,60,70,80,90$

Scheme 3. 
H. KUDO et al.

Table II. The continuous insertion reaction of PPS with BPhe ${ }^{\mathrm{a}}$

\begin{tabular}{|c|c|c|c|c|c|c|c|}
\hline \multirow[t]{2}{*}{ Run } & Feed Molar Ratio & \multirow[t]{2}{*}{$\begin{array}{l}\text { Yield } \\
(\%)^{\mathrm{b}}\end{array}$} & Polymer Composition ${ }^{c}$ & \multirow[t]{2}{*}{$\begin{array}{c}M_{\mathrm{n}, \mathrm{SEC}}{ }^{\mathrm{d}} \\
\left(M_{\mathrm{w}} / M_{\mathrm{n}}\right)\end{array}$} & \multirow[t]{2}{*}{$M_{\mathrm{n}, \mathrm{NMR}}{ }^{\mathrm{e}}$} & \multirow[t]{2}{*}{$n_{\mathrm{D}}^{\mathrm{f}}$} & \multirow[t]{2}{*}{$\begin{array}{c}\text { Sulfur Content } \\
(\%)\end{array}$} \\
\hline & PPS/BPhe & & PPS/BPhe & & & & \\
\hline 1 & $10 / 1$ & 90 & $10 / 1$ & $2000(1.45)$ & 2000 & $-\mathrm{g}$ & 17.6 \\
\hline 2 & $20 / 1$ & 92 & $20 / 1$ & $3200(1.51)$ & 3600 & $\_^{g}$ & 18.6 \\
\hline 3 & $30 / 1$ & 91 & $30 / 1$ & $5400(1.56)$ & 5300 & $\_\mathrm{g}$ & 18.7 \\
\hline 4 & $40 / 1$ & 91 & $40 / 1$ & $7100(1.60)$ & 7000 & $\ldots \mathrm{g}$ & 18.7 \\
\hline 5 & $50 / 1$ & 92 & $50 / 1$ & $8300(1.56)$ & 8600 & 1.612 & 18.9 \\
\hline 6 & $60 / 1$ & 89 & $60 / 1$ & $10400(1.56)$ & 10300 & 1.612 & 18.9 \\
\hline 7 & $70 / 1$ & 93 & $70 / 1$ & $12000(1.63)$ & 12000 & 1.614 & 18.9 \\
\hline 8 & $80 / 1$ & 92 & $80 / 1$ & $13500(1.64)$ & 13600 & 1.614 & 18.9 \\
\hline 9 & $90 / 1$ & 93 & $90 / 1$ & $15200(1.65)$ & 15300 & 1.614 & 18.9 \\
\hline
\end{tabular}

${ }^{a}$ The reaction of PPS and BCA[8] was carried out in the presence of TBAC as a catalyst in NMP at $90^{\circ} \mathrm{C}$ for $24 \mathrm{~h}$. ${ }^{\mathrm{b}}$ Hexane-insoluble parts. ${ }^{\mathrm{c}}$ The degree of continuous insertion reaction of PPS into BCA[8] (DI) was calculated by ${ }^{1} \mathrm{H}$ NMR. ${ }^{\mathrm{d}}$ Estimated by SEC based on polystyrene standards; eluent: THF. ${ }^{\mathrm{e}}$ Calculated by ${ }^{1} \mathrm{H}$ NMR. ${ }^{\mathrm{f}}$ Average values of refractive-indices determined by ellipsometer using $0.6328 \mu \mathrm{m} .{ }^{\mathrm{g}}$ Not determined.

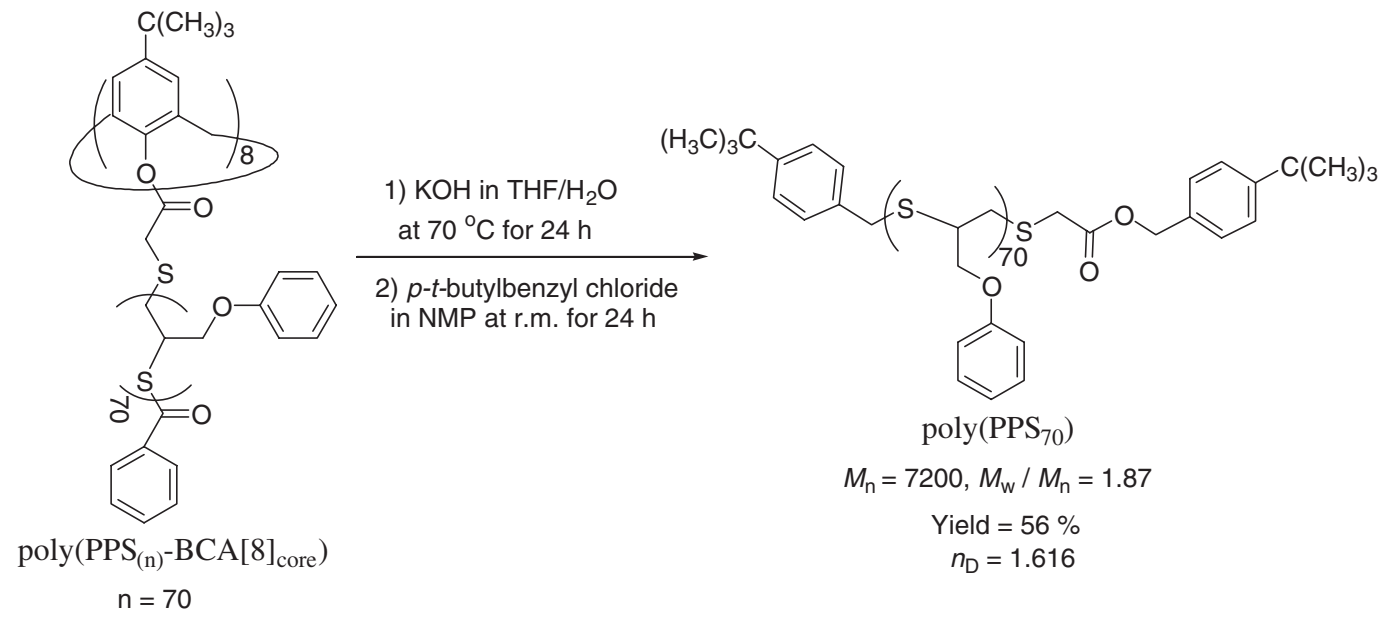

Scheme 4.

These results show that the value of refractive-index of star shaped polymers is higher than that of the linear ones, because of that star shaped polymers have compact structure and high segment density.

\section{SUMMARY}

In summary, octa-arms star-shaped polysulfides poly $\left(\mathrm{PPS}_{(n)}-\mathrm{BCA}[8]_{\text {core }}\right)$ were synthesized by the radiating from $p$ - $t$-butylcalix[8]arene derivative core. The continuous insertion reaction of PPS into thioester moieties of $\mathrm{BCA}[8]$-core proceeded quantitatively in the presence of TBAC as a catalyst, affording the star-shaped polymers poly($\left(\mathrm{PPS}_{(n)}-\mathrm{BCA}[8]_{\text {core }}\right)$. It was found that the arm-lengths of poly $\left(\operatorname{PPS}_{(n)}-\mathrm{BCA}[8]_{\text {core }}\right)$ could be controlled easily by the feed ratios of [PPS]/ $\left[(\mathrm{BCA}[8] \times 8)\right.$. The values $\left(n_{\mathrm{D}} \mathrm{s}\right)$ of refractive-indices of poly $\left(\operatorname{PPS}_{(n)}-\mathrm{BCA}[8]_{\text {core }}\right)$ increased with their sulfur contents. This means that $n_{\mathrm{D}} \mathrm{s}$ could be controlled by the arm length of star-shaped polymers. Furthermore, we examined the $n_{\mathrm{D}} \mathrm{s}$ of the linear polymers poly$\left(\operatorname{PPS}_{(n)}\right.$-Bphe) which skeletons are almost the same as the star-shaped polymers, and it could be concluded that $n_{\mathrm{D}} \mathrm{s}$ were higher than those of the linear ones due to their compact structures and high segment densities.

Other various star-shaped polysulfides can also be obtained by the radiating from cyclic thioesters which can be derived from the $p$-methylcalix[6]arene and calix[4]resorcinarene as the cores. The syntheses and properties of these calixarenes are now under investigation.

\section{REFERENCES}

1. For example: "Refractive-index Control of Transparent High Polymers," Gakkaishuppan Center, Tokyo, 1998.

2. J. D. Cawley and J. W. H. Faber, U.S. Patent 3, 799, 972 (1974).

3. T. Matsudo, Y. Funae, M. Yoshida, and T. Yamamoto, 
J. Appl. Polym. Sci., 76, 50 (2000).

4. For example: A. Kameyama, Y. Murakami, and T. Nishikubo, Macromolecules, 29, 6676 (1996).

5. For example: A. Hara, Y. Ohishi, M. Kakimoto, and Y. Imai, J. Polym. Sci., Part A: Polym. Chem., 29, 1933 (1991).

6. For example: E. Koyama, F. Sanda, and T. Endo, Macromolecules, 31, 1495 (1998).

7. S. P. Meneghetti, P. J. Lutz, and D. Rein, "Star and Hyperbranched Polymers," M. K. Mishra, S. Kobayashi, Ed., Marcel Dekker, New York, 1999, pp. 27-57.

8. A. Hirao, K. Kawasaki, and T. Higashihara, Macromolecules, 37, 5179 (2004).

9. A. Suzuki, D. Nagai, B. Ochiai, and T. Endo, Macromolecules, 37, 8823 (2004).

10. K. Hirao and Y. Tokuda, Macromolecules, 36, 6081 (2003).

11. F. Sanda, H. Sanada, Y. Shibasaki, and T. Endo, Macromolrcules, 35, 680 (2002).

12. S. Ingrish, O. Nyuken, and M. K. Mishra, Plast. Eng., 53, 77 (1999).

13. J. P. Kennedy and S. Jacob, Acc. Chem. Res., 31, 835 (1998).

14. Y. C. Bae and R. Faut, Macromolecules, 31, 2480 (1998).

15. H. Deng, S. Kanaoka, M. Sawamoto, and T. Higashimura, Macromolecules, 29, 1772 (1996).

16. J. Du and Y. Chen, Macromolecules, 37, 3588 (2004).

17. K. Ishizu, J. Park, T. Shibuya, and A. Sogabe, Macromolecules, 36, 2990 (2003).

18. T. Tarashima, M. Kamigaito, K. Y. Baek, T. Ando, and M. Sawamoto, J. Am. Chem. Soc., 125, 5288 (2003).

19. A. W. Bosman, A. Heumann, G. Klaerner, D. Benoit, J. M. J. Frechet, and C. J. Hawker, J. Am. Chem. Soc., 123, 6461 (2001).
20. K. Y. Baek, M. Kamigaito, and M. Sawamoto, Macromolecules, 34, 215 (2001).

21. K. Y. Baek, M. Kamigaito, and M. Sawamoto, Macromolecules, 34, 7629 (2001).

22. X. Zhang, J. Xia, and K. Matyjaszewski, Macromolecules, 33, 2340 (2000).

23. S. Jacob, I. Majoros, and J. P. Kennedy, Macromolecules, 29, 8631 (1996).

24. S. Jacob and J. P. Kennedy, Polym. Bull., 41, 167 (1998).

25. J. S. Shim and J. P. Kennedy, Polym. Bull., 44, 493 (2000).

26. D. L. Hull and J. P. Kennedy, J. Polym. Sci., Part A: Polym. Chem., 39, 1525 (2001).

27. J. Ueda, M. Kamigaito, and M. Sawamoto, Macromolecules, 31, 6762 (1998).

28. D. Taton, M. Saule, J. Logan, R. Duran, S. Hou, E. L. Chaikof, and Y. Gnanou, J. Polym. Sci., Part A: Polym. Chem., 41, 1669 (2003).

29. A. Kameyama, M. Kiyota, and T. Nishikubo, Tetrahedron Lett., 35, 4571 (1994).

30. A. Kameyama, K. Shimotsuma, and T. Nishikubo, Macromol. Rapid Commun., 15, 335 (1994).

31. D. R. Robello, N. Yamaguchi, T. Blanton, and C. Barmes, J. Am. Chem. Soc., 126, 8118 (2004).

32. S. H. Goodson and B. M. Novak, Macromolecules, 34, 3849 (2001).

33. P. V. Caeter and E. J. Goethals, Macromol. Rapid Commun., 18, 393 (1997).

34. H. M. Kok, S. Becker, F. Schuch, T. Pakula, and K. Mullen, Macromol. Chem. Phys., 203, 1106 (2002).

35. R. F. Storey, K. A. Shoemake, J. M. Mays, and S. Harville, J. Polym. Sci., Part A: Polym. Chem., 35, 3767 (1997). 